\title{
Pengontrolan Diri Kaum Remaja dengan Pengamalan Thariqat Qodiriyah Naqsyabandiyah di Kabupaten Bandung
}

\author{
Abdul Wasik ${ }^{*}$ \\ 1 UIN Sunan Gunung Djati Bandung, Indonesia; e-mail: abdulwasik52@gmail.com \\ * Correspondence
}

Received: 2020-10-21; Accepted: 2020-10-28; Published: 2020-12-31

\begin{abstract}
This article is based on the rise of radical Islamic movements, terrorism, and the youth movement for young people. In addition to these symptoms, it turns out that there are movements of young people who take Sufism's path through the teachings of the Sufi order at the Alwi Mosque, Bandung Regency. With a qualitative approach, this sociological research finds youths who practice the Sufi order's instructions solidly. They carry out religious deepening and soul purification by carrying out various kinds of Sufi order worship. Departing from this, this research discusses the philosophical foundation of young people following the Sufi order, young people's activities when they have a relationship, and the benefits during their development. The results showed that young people who follow Sufi order tend to have a pragmatic instrumental philosophical foundation (alZarai'iy), and the Tariqat Qodiriyah Naqshabandiyah performance does not differentiate between young and old. However, at least five benefits for young people to follow the Sufi order: murshid guidance, adding siblings, togetherness, and solidarity, avoiding religious deviations, and being more self-controlled.
\end{abstract}

Keywords: esoterism; sociology of religion; sufism; youth religiosity.

Abstrak: Artikel ini dilatarbelakangi oleh maraknya gerakan Islam radikal, terorisme dan gerakan pemuda hijrah bagi kalangan anak muda. Selain gejala tersebut, ternyata terdapat gerakan anak muda yang menempuh jalan tasawuf melalui ajaran tarekat di Masjid Alwi Kabupaten Bandung. Dengan pendekatan kualitatif, penelitian sosiologis ini mendapati para pemuda yang mengamalkan ajaran tarekat secara solid. Mereka melakukan pendalaman agama dan penyucian jiwa dengan melalukan berbagai macam peribadatan tarekat. Berangkat dari hal tersebut, penelitian ini membahas mengenai landasan filosofis anak muda mengikuti tarekat, kegiatan anak muda saat bertarekat, dan manfaat dalam masa perkembangannya. Hasil penelitian menunjukkan bahwa anak muda yang mengikuti tarekat cenderung memiliki landasan filosofi pragmatis instrumental (al-Dzarai'iy) dan amaliah Thariqat Qodiriyah Naqsyabandiyah tidak membedakan antara yang muda ataupun yang tua. Meskipun demikian, setidaknya terdapat lima manfaat anak muda mengikuti tarekat, yaitu: bimbingan mursyid, menambah saudara, kebersamaan dan solidaritas, menghindari penyimpangan agama, dan diri lebih terkontrol.

Kata Kunci: tasawuf; esoterisme; keberagamaan pemuda; sosiologi agama

\section{Pendahuluan}

Indonesia tergolong negara dengan jumlah penduduk muslim terbanyak di dunia. Jika ditelusuri lebih dalam ternyata penyebaran agama Islam di Indonesia sangat erat dipengaruhi oleh ajaran tasawuf (tarekat); proses penyebaran menggunakan sistem kelembutan dan dalam menjalankan keagamaan lebih mengutamakan pada aspek esoteris (mendalam) dari pada aspek eksoteris (makna luar), Corak Islam tersebut diadaptasi dari India Selatan terus berkembang ke wilayah timur, Semenanjung Malaya dan Nusantara (Syam, 2013). 
Menurut Abu Bakar Atjeh bahwa ajaran tasawuf mengklasifikasikan keagamaan seseorang berdasarkan 4 tahapan, yaitu: tahapan amalan-amalan lahir diperbaiki melalui ajaran syari'ah, amalanamalan batin (hati) melalui ajaran tarekat, sedangkan mengamalkan segala rahasia yang gaib itu amalan hakikat, dan tujuan akhir adalah ma'rifat, yakni mengenal hakikat Allah baik sifat, zat maupun perbuatannya (Atjeh, 1996). Meskipun cikal bakal perkembangan agama Islam di Indonesia di latar belakangi oleh ajaran tasawuf, akan tetapi tidak semua muslim di Indonesia mau mendalaminya, mayoritas para penggiat ajaran tasawuf dalam tarekat adalah orang tua (Wawancara dengan HM, Wakil Talqin TQN, 03/02/2020). Anak muda lebih condong pada kesuksesan pribadi; ekonomi, keungan dan materiil dibandingkan dengan agama (Jalaluddin, 2015). Anak muda usia dua puluhan adalah sebagai "periode dalam kehidupan yang paling tidak religius." (Hurlock, 2002).

Anak muda yang kemudian disebut pemuda di Negara Indonesia adalah warga negara berusia 16 sampai 30 tahun yang mana usia ini merupakan periode penting perkembangan dan pertumbuhan, (Undang-Undang Republik Indonesia Nomor 40 Tahun 2009, n.d.) dan masa ini juga merupakan masa pencarian makna hidup, masa 'coba-coba' dan masa aktualisasi diri paling tinggi pada masa periode perkembangan manusia. Maka tidak heran jika pemuda yang memiliki kecondongan terhadap agama lebih rentan mengikuti Gerakan Islam yang mengutamakan pada aspek eksoteris.

Penelitian sebelumnya telah menunjukan bahwa religius keagamaan anak muda lebih mudah masuk pada gerakan radikalisme seperti penelitian yang dilakukan oleh Rindha Widyaningsih, Sumiyem, dan Kuntarto menunjukkan bahwa anak muda di Banyumas memiliki kerentanan terpapar dan terpengaruh paham-paham radikalisme yang dipengaruhi oleh kondisi psikologis, dan sikap keberagamaan (Widyaningsih, Sumiyem, \& Kuntarto, 2017). Selain itu, BIN (Badan Intelijen Negara) di tahun 2017 juga menunjukkan bahwa dari jumlah seluruh mahasiswa di perguruan tinggi yang terpapar gerakan radikalisme dan terorisme sebanyak 39 persen (Wishnugroho Akbar, 2018).

Selain gerakan radikalisme dan terorisme di kalangan anak muda, belakangan ini juga semakin marak gerakan pemuda hijrah. Tercatat pada awal Januari tahun 2018, di akun Instagram, 600.200 mengikutinya dan pada halaman fans page Facebook mencapai 56.500 serta yang berlangganan di saluran Youtube mencapai 42.400 (Abdurrahman, 2020). Jika diamati secara mendalam, yang paling mendominasi adalah anak muda kelas menengah perkotaan. Hal ini terjadi diduga karena gerakan pemuda hijrah masif di media sosial.

Meskipun demikian, dibalik maraknya gerakan Islam radikal, terorisme, dan gerakan pemuda hijrah bagi kalangan anak muda di kota-kota besar, ternyata terdapat gerakan anak muda yang menempuh jalan tasawuf melalui tarekat; seperti halnya gerakan tarekat anak muda di Kabupaten Bandung tepatnya di Masjid Muhammad Alwi Jl. Pesantren Timur No. 1 Pamekaran Soreang Kabupaten Bandung, Masjid tersebut merupakan pusat zawiyah TQN di wilayah Bandung dan disanalah salah satu pusat anak muda di Kabupaten Bandung melakukan pendalaman agama dan penyucian jiwa dengan melalukan berbagai macam peribadatan tarekat; mulai dari pujian-pujian, wirid-wirid, manaqiban dan kegiatan-kegiatan khusus lainnya.

Menurut Imam Nawawi al-Bantani tarekat adalah melaksanakan amaliah wajib dan amaliah sunah, meninggalkan larangan, menghindari perbuatan mubah yang tidak bermanfaat, sangat berhatihati dalam menjaga diri dari subhat.

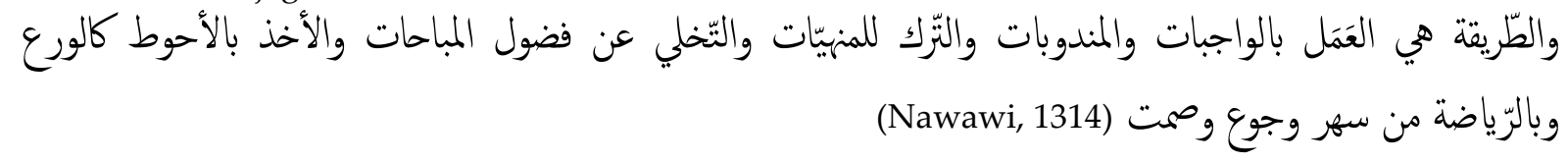

Tujuan utama tarekat menurut Harun Nasution adalah menjadikan seseorang lebih mudah untuk bisa berada di dekat Allah dengan menggunakan jalan yang dicontohkan atau disiapkan oleh guru tarekat (Nasution, 2018), dan setiap tarekat memiliki amalan masing-masing. Berlatarbelakang itulah yang mendasari perubahan makna tarekat. Tarekat yang awalnya hanya sebagai jalan, cara, dan metode yang ditempuh seorang salik menuju spiritual tertinggi, kemudian tarekat menjadi istitusi sosial keagamaan (Riyadi, 2014). Jumlah istitusi sosial keagamaan tarekat tidak dapat diketahui secara pasti, akan tetapi Jam'iyah Nadhotul Ulama (NU) telah menghimpun tarekat-tarekat di Indonesia. 
Terdapat dua kategori tarekat, pertama tarekat mu'tabarah dan tarekat ghoiru mu'tabarah. Menurutnya terdapat 44 tarekat yang dinilai $m u^{\prime}$ tabarah dan salah satunya adalah TQN.

Tarekat TQN menurut Zamakhsyari Dhofier merupakan tarekat terbesar di Pulau Jawa.Ismail, "Fenomena Tarekat di Zaman Now (Telaah Atas Ajaran Dan Amalan)." Dan selain itu keunikan tarekat ini juga adalah kelahirannya hasil dari penggabungan dua tarekat besar yaitu TQN, dengan model amalan zikir jahr (zikir dengan bersuara) inti dari ajaran Tarekat Qodiriyyah dan zikir sirri (zikir dalam hati, atau zikir lathoif) inti dari ajaran tarekat Naqsabandiyah. Dari kedua amalan zikir tersebut diharapkan dapat lebih efisian dan lebih cepat untuk para murid dapat mencapai derajat kesufiannya. Berangkat dari sinilah ketetarikan peneliti untuk menganalisis dan mendalami fenomena anak muda menempuh jalan kesufian TQN di Kabupaten Bandung.

Banyak peneliti yang telah menekuni secara mendalam mengenai tarekat. Tercatat dalam beberapa dekade ini adalah Martin Van Bruinessen (Bruinessen, 1992), Dadang Kahmad (Kahmad, 2002), Nur Syam (Syam, 2013), Aly Mashar Ismail (Mashar, 2016), Asep Usman Ismail (Ismail, 2018), Masduki (Masduki, Hartono, \& Rosidi, 2017), dan beberapa peneliti lainnya. Dari semua peneliti yang mengkaji mengenai tarekat, berbagai macam metode/pendekatan yang digunakan, baik pendekatan historis, sosiologis, antopologis, dan tidak jarang mencoba menganalisis dengan mengaitkannya pada keilmuan lainnya. Selain penelitian tentang tarekat, terdapat penelitian yang membahas mengenai keagamaan/religius anak muda, antara lain adalah Ross dan Haward Bell terhadap 13.000 anak muda di Maryland, hasil penelitian menunjukkan bahwa minat anak muda terhadap masalah ideal, keagamaan dan sosial hanya mencapai $21 \%$, sisanya cenderung pada kesuksesan pribadi khususnya masalah materiil (Jalaluddin, 2015). Peneliti lain adalah Rindha Widyaningsih, Sumiyem dan Kuntarto pada tahun 2017 yang menunjukkan bahwa anak muda di Banyumas sangat rentan terpengaruh dan terpapar gerakan radikalisme yang dipengaruhi oleh kondisi psikologis, politik dan keagamaan yang lemah (Widyaningsih et al., 2017). Dan penelitian Muhammad Sufyan Abdurrahman yang membahas mengenai perilaku keagamaan anak muda yang mengikuti Shift di Bandung dalam penelitiannya, ia mencoba untuk menganalisis fenomena anak muda yang mengikuti gerakan Pemuda Hijrah dengan menggunakan pendekatan kualitatif dan menggunakan metode studi pustaka, dalam penelitiannya ia menemukan bahwa motif mengikuti gerakan ini karena dorongan masa lalu, teman, orang lain dan harapan masa depan. Meski sudah banyak yang telah mengkaji tarekat dan minat keagamaan anak muda. Kendati demikian, penelitian ini mencoba untuk menunjukkan hal yang tidak kalah pentingnya dari penelitian sebelumnya, yaitu membahasa mengenai landasan filosofis anak muda mengikuti tarekat, kegiatan anak muda saat bertarekat, dan manfaat yang bagi masa perkembangannya.

\section{Metode Penelitian}

Penelitian kualitatif ini menggunakan metode studi kasus dari fenomena yang terjadi. Melalui observasi, wawancara, dan diperkuat dengan kajian literatur terkait tema fenomena keagamaan di kalangan para remaja. Di sini ditelusuri kesadaran murni atau realitas puncak yang menyebabkan seseorang melakukan aksi sosial keagamaan baik pikiran, tindakan, dan perilaku kelompok. Tujuan (output) yang diharapkan dari model penelitian ini adalah mengkonstruk ilmu yang sifatnya ideografik dan akan menghasilkan kajian ilmiah yang mengandung muatan nilai (value laden).

\section{Hasil Penelitian}

Nama tarekat Thariqah Qadiriyah Naqsyabandiyah (TQN) dinisbatkan kepada dua tarekat yang melatarbelakanginya, tarekat Qoodiriyyah dan tarekat Naqsyabandiyyah. Nama lengkap pendiri tarekat ini adalah Ahmad Khatib ibn 'Abdu Ghaffar Al-Sambasi (Kalimantan Timur), wafat pada tahun 1878 M. Beliau menghabiskan sebagian besar hidupnya di Makkah dan daerah sekitarnya untuk menjadi Syekh besar Masjid Al-Haram Makkah Al-Mukarromah dan mengajarkan serta mencontohkan amaliah tasawuf (tarekat) kepada murid-muridnya. Sebelum beliau mendirikan tarekat ini, beliau terlebih dahulu diangkat menjadi mursyid tarekat Qodiriyyah dan masyarakat mengetahui bahwa beliau juga mursyid tarekat Naqsyabandiyyah. Berlandaskan pada ajaran tarekat Qoodiriyyah 
yang dapat memodifikasi amaliah ketika sudah pada derajat mursyid maka beliau menghabungkan dua tarekat tersebut (Tim Karya Ilmiah Purna Siswa, 2014).

Secara historis, pada abad ke-19 diperkirakan awal mula penyebaran tarekat TQN di Indonesia. Tarekat ini mendapatkan pengikut dengan jumlah besar dan menggantikan kepopuleran tarekat Sammaniyah yang waktu itu tarekat ini merupakan tarekat dengan jumlah pengikut terbayak di Indonesia dan sampai saat ini TQN tergolong tarekat terbesar di Indonesia serta memiliki pengaruh besar terhadap kemajuan Indonesia. Setelah Syeh Ahmad Khatib wafat, kedudukan beliau digantikan oleh salah satu muridnya yaitu Kiai Tolhah dari Cirebon, dan kemudian tepat pada tanggal 5 September 1950 setelah beliau wafat kepemimpinan tarekat ini dilanjutkan oleh syeh Abdullah Mubarrok Bin Nur Muhammad (Abah Sepuh) yang merupakan murid Kiai Tolhah dan pada masa kepemimpinan syeh Abdullah beliau mendirikan Pondok Pesantren Suryalaya sebagai pusat zawiyah tarekat di Jawa Barat bagian tengah dan timur. Hampir selama 51 tahun beliau memimpin, kemudian pada tahun 1956 beliau wafat. Kepemimpinan Pondok Pesantren dan tarekat dilanjutkan putra kelima beliau, Ahmad Shohibulwafa Tajul Arifin atau dengan panggilan populer Abah Anom. pada tahun 2011 beliau wafat dan kepemimpinan TQN dilanjutkan oleh Syekh Muhamad Abdul Gaos Saefulloh Maslul Al-Qodiri An-Naqsyabandi Al-Kamil Al-Muwaffaq ra QS (Abah Aos) (Saefulloh, 2014) sampai sekarang.

Tentu setiap ajaran tarekat memiliki ciri khas atau metode amaliah yang berbeda-beda, kalaupun memiliki amalan yang sama itu karena memang sumber awal dari Nabi Muhammad SAW. Amalan spiritual tarekat patutnya untuk terus diamalkan oleh semua ikhwan tarekat yang telah masuk (talqin). Berikut amaliah secara umum TQN pada masa kepemimpinan mursyid saat ini: Zikir harian, Khotaman, Sholawat, Tanbih, Tawasul, Manqobah, Amaliah Harian, Amaliah Tahunan, Tarhim, Ziarah, dan Doa (Saeful, n.d.).

Jika dilihat dari peta penyebarannya, tempat-tempat manaqiban para pengikut TQN secara geografis terkonsentrasi di wilayah Bandung Timur dan Selatan. Sebagian besar dari jumlah tempat manaqiban itu berada di kedua wilayah tersebut yang secara sosiologis dapat dikategorikan sebagai wilayah pemukiman kelas menengah ke bawah sebaliknya di daerah Bandung Utara dan Bandung Barat dikenal sebagai daerah pemukiman elit dengan tingkat sosial ekonomi menengah ke atas. Jumlah anak muda pengikut TQN di kabupaten Bandung tidak dapat diketahui secara pasti, sebab di samping status keanggotaannya tidak tercatat secara formal, tarekat juga merupakan ciri umum komunitas keagamaan jenis sekte yang bersifat pribadi dan atau rahasia. Dalam proses recruitment keanggotaan bersifat sukarela dan kampanye untuk mengikuti tarekat ini tidak dilakukan secara khusus dan intensif. Proses penyebarannya lebih bersifat personal sehingga memungkinkan calon ikhwan untuk memikirkan secara lebih matang untuk menerima ataupun menolak menjadi ikhwan.

Pada tahun 2002 penelitian yang dilakukan oleh Dadang Kahmad menunjukkan perkiraan angka drop out dari keanggotaan ikhwan TQN cukup tinggi (lebih dari 60\%) (Kahmad, 2002). Jadi, jika ada seratus orang ditalkin dan dibaiat, diperkirakan kurang dari empat puluh orang melanjutkan secara konsisten komitmen kejamaahannya, sedangkan sisanya tidak bisa aktif dan bahkan keluar dari kejamaahan.

Untuk mempertahankan semangat menjalankan amaliah tarekat, khususnya ikhwan muda di Kabupaten Bandung, mereka membuat Grup WhatsApp Pemuda Pecinta Kesucian Jiwa (PKJ), meskipun dalam relita tidak seluruh ikhwan muda masuk grup tersebut, tetapi paling tidak grup tersebut dapat membantu memperkuat amaliah dan untuk mempertahankan silaturrahmi antar anggota. Di grup tersebut dilakukan terus menerus diskusi membahas isu kontemporer; baik ekonomi, pendidikan dan bahkan politik serta belajar bersama dengan mendengarkan ceramah via rekaman atau video para guru tarekat (mursyid atau wakil talqin). Selain Grup WhatsApp, hal yang paling utama untuk mempertahankan amaliah adalah mengikuti kegiatan manaqiban dan khataman (Wawancara dengan MN, anggota Grup WhatsApp PKJ, 10/05/ 2020).

Perlu diketahui, bahwa rentang usia pemuda yang mengikuti tarekat kebanyakan pada rentang 20-30 an dengan latar belakang yang bervariasi, baik sedang menempuh pendidikan atau bekerja; ada yang guru, buruh harian, pedagang dan lain sebagainya. Sedang, pemuda yang menjadi ikhwan jika 
dilihat latar belakang pendidikan formal dan pendidikan keagamaanya; terdapat dari pendidikan SMP sampai S1 dan rata-rata menempuh pendidikan SMA-Sederajat dan terdapat juga yang menempuh pendidikan pesantren cukup lama dan ada juga yang baru mulai mendalami ilmu agama. Meskipun latar belakang ikhwan muda yang bervariasi, tetapi dalam kegiatan tarekat/dalam menjalankan amaliahnya belum ada perbedaan; duduk sederajat bersama.

\section{Landasan Filosofis}

Kajian filsafat sering kali menjadi dasar setiap disiplin ilmu pengetahuan. Hal itu dapat diterima karena pada dasarnya setiap ilmu berlandaskan pada pemikiran yang mendasar (filsafat). Filsafat selalu mencari dan mengamati keadaaan dunia dari hal fisik maupun meta fisik serta makna dan nilainilainya. Dengan berlandas pada filsafat artinya ia telah berusaha mencari jawaban setiap pertanyaan tentang sifat dasar dan asal muasal semua hal ada dan hal yang menjadi tujuan hidupnya (Hariko, 2017).

Teori Landasan filosofis dalam Pendidikan Islam Perspektif Muhammad Jawwad Ridla mengungkapkan bahwa terdapat tiga macam dasar sesorang dalam menempuh pendidikan yaitu; Religius-Konservatif (al-Muhafidz), aliran ini condong pada kemurnian agama, ia memiliki pandangan terhadap ilmu sangat sempit; menganggap ilmu ada yang wajib yaitu tentang tatacara beribadah kepada Allah dan yang ilmu yang wajib kifayah seperti ilmu keduniawian misal kedokteran arsitek dan lain sebagainya. Religius-Rasional (al-Diniy al-'Aqlaniy), aliran ini didasarkan pada spiritualitas, yakni dibagun atas dasar kesadaran yang berasal dari Tuhan berupa wahyu dan empiris-rasional yang menjadikan kesadaran ilmiah atau ciri khas teori ini adalah perpaduan antara wahyu dan rasioal. Pragmatis Instrumental (al-Dzarai'iy), aliran ini memiliki pandangan bahwa semua kelimuan haruslah berdasarkan pada kebutuhan lansung manusia baik kebutuhan ruhaniah-spiritual maupun kebutuhan jasmaniah-material (Kurniawan, 2019).

Menjadi pengikut salah satu aliran keagamaan, mengisyaratkan adanya pengalaman unik dari kehidupan manusia. Sebab, proses keluar masuk suatu aliran keagamaan sangat berbeda dengan proses keluar masuk dalam aspek lain dari kehidupan manusia. Proses memasuki TQN, pada dasarnya sama dengan memasuki aspek kehidupan yang sakral dan penuh misteri. Proses ini terjadi dengan melibatkan lubuk yang terdalam dari jiwa manusia, penuh dengan pertimbangan kompleks dari diri maupun lingkungan sosial budaya yang bersangkutan. berbagai aspek, seperti aspek psikologis, sosiologis, dan antropologi dari diri maupun lingkungan sosial budaya yang bersangkutan.

Proses pengambilan keputusan masuk atau tidaknya seseorang menjadi ikhwan TQN, khususnya di wilayah Kabupaten Bandung, berlangsung melalui rangkaian peristiwa yang hampir sama dengan proses pengambilan keputusan untuk pindah dari suatu keyakinan ke keyakinan lain. Sekurangkurangnya, ada tiga pola tahapan yang ditemukan dalam proses perubahan kepercayaan seseorang, yaitu sebelum mengambil keputusan, pada saat memutuskan, dan sesudah pengambilan keputusan.

Keadaan umum diri individu sebelum mengambil keputusan. Tahapan ini berpengaruh pada proses pengambilan keputusan apakah seseorang akan berpindah atau menetap pada keyakinan semula. Keadaan individu yang taat beragama, misalnya akan berbeda dengan kondisi seseorang yang tidak taat beragama.

Proses sebelum individu mengambil keputusan mengikuti ajaran tarakat ini, terdapat beberapa latarbelakang atau motif, yang pertama ketertarikan untuk mulai ingin masuk tarekat karena melihat figur yang dianggap memiliki karakter yang mulia; sopan, santun dan berbudi yang sifat-sifat tersebut sangat diharapkan bisa terdapat pada diri pribadi. Seperti halnya yang telah diungkapkan oleh Nugraha bahwa: Mengikuti ajaran tarekat karena melihat contoh pribadi yang baik, salah satu ikhwan mengaku bahwa ia masuk ke tarekat karena melihat sosok penjual jajan asongan di tempat ia sekolah yang memiliki budi perkerti dan akhlak mulia; sabar, santun dan rajin berjamaah (sholeh); dan ketika ditelusuri ternyata penjual itu mengikuti ajaran tarekat, dan disitulah ketertarikan untuk mencari tahu tentang tarekat (Wawancara dengan NG, pengikut TQN, 10/05/ 2020). Kedua keikutsertaan individu sebelum mengambil keputusan untuk mengikuti ajaran tarekat karena dipengaruhi oleh lingkungan; baik lingkungan keluarga maupun lingkungan masyarakat secara luas. Hal ini yang dirasakan oleh 
Aldi Sahara, menurut pengakuannya, bahwa mengikuti ajaran terekat karena sudah lumlah atau sudah sangat biasa dilakukan; sejak kecil ia diajak orang tuanya untuk mengikuti kegiatan tarekat, berawal dari situlah ia mulai mengenal ajaran tarekat (Wawancara dengan NG, pengikut TQN, 07/05/ 2020). Ketiga keguncangan dalam diri akan kebutuhan terhadap religiusitas yang mengantarkan seseorang untuk mulai mencari jalannya, sehingga ia mulai mencari dan menggali mengenai berbagai macam aliran-aliran atau golongan-golongan kegiatan keagamaan yang dapat mencukupi atas kebutuhan religiusitasnya (Wawancara dengan DMY, pengikut TQN, 16/05/ 2020). Dan keempat, sesuai dengan masa perkembangan anak muda, ternyata dalam penelitian ditemukan bahwa ia sebelum mengikuti ajaran tarekat hanya karena ia ingin coba-coba dan iseng (Wawancara dengan $\mathrm{MN}$, pengikut TQN, 19/05/ 2020).

Kondisi pada saat proses pengambilan keputusan itu dilakukan. Perpindahan seseorang dari suatu keyakinan ke keyakinan lainnya mengindikasikan adanya perubahan tata nilai yang dianut, yang pada gilirannya akan menentukan bentuk perilaku keagamaan yang diperankannya. Keadaan subjektif pelaku perpindahan setelah pengambilan putusan. Seseorang yang telah menetapkan untuk berpindah keyakinan, pada umumnya, mengindikasikan adanya perubahan perilaku keagamaan yang diperankannya. Maka dari penjabaran tersebut dapat disimpulan bahwa anak muda yang mengikuti ajaran terekat cenderung pada landasan filosofis pendidikan Pragmatis Instrumental (al-Dzarai'iy), bagaimana awal mula pencarian yang didasarkan inginan pencapaian pada suatu 'tempat' atau kebutuhan akan rasa tenang, nyaman, dan mendapatkan kualitas beribada yang lebih baik.

Secara teknis, seseorang yang telah menjadi ikhwan setidaknya sebelumnya talah melewati lima tahapan. Pertama munculnya niat untuk mencari jalan yang dapat mendekatkan diri kepada Allah; khususnya jalan tarekat. Ketika rasa ini muncul maka aktivitas peribadataan yang dilaksanakan oleh TQN terbuka untuknya, agar ia mulai mencari tau dan memahami karakteristik dan sifat-sifat dasar yang ada di TQN. Kedua, jika merasa sesuai, maka pada tahap selanjutnya, ia dapat menggali lebih dalam mengenai ajaran tarekat kepada ikhwan lain atau bahkan sampai kepada mursyid, atau sering kali seorang mursyid/wakil talkin akan menjelaskan mengenai landasan ajaran TQN kepada kandidat ikhwan, meskipun demikian, tetap ia diberi keleluasan untuk menentukannya sendiri, apakah melanjutkan mengikuti ajaran tarekat atau masih membutuhkan informasi lebih dalam atau bahkan menghentikan keterlibatannya dalam tarekat. Ketiga, pada tahapan ini, diarahkan untuk melaksanakan sholat istikharah berharap mendapatkan petunjuk dan arahan dari Allah dengan bimbingan seorang wakil mursyid atau mubalig. Selain bertujuan untuk mengharapkan petunjuk dan barokah, secara psikologis memperoleh dukunan moril untuk memperkuat niat dan keyakinannya. Keempat, jika sudah merasa yakin, maka ia harus mengutarakan kesanggupan untuk menjalankan ajaran dan mentaati segala ketentuan yang ada di tarekat. Kelima, tahap akhir, setelah menyelesaikan tahapan sebelumnya tahapan ini adalah pintu gerbang utama agar dapat menjadi bagian dari TQN yaitu baiat/talkin (Kahmad, 2002). Dan menurut pengakuan ikhwan, ketika sudah ditalkin timbulah kenikmatan tersendiri dalam berzikir dan beribadah yang sebelumnya belum pernah dirasakan sebelum ditalkin.

\section{Sistem Ajaran}

Murid adalah pengikut yang mengharapkan pengalaman dan pengetahuan tarekat yang diikuti, dengan melalui tahapan-tahapan; mendengarkan, memahami, mengetahui, menyaksikan dan makrifat (Alba, 2011, p. 151). Para guru tarekat menyadari bahwa masyarakat 'awam' tidak mungkin mencapai pengalaman fana' dan makrifat pada Allah yang menjadi inti ajaran tasawuf. Oleh karena itu para guru tarekat pada umumnya membagi murid-murid mereka menjadi dua lapis. Yaitu gologan 'awam' dan kader-kader yang mereka nilai akan mampu mencapai tingkat khowas. Bagi golongan awam hanya diajar dan dilati menjalankan tasawuf dalam batas kemampuannya, dalam istilah jawa disebut rubuhrubuh gedhang (ikut-ikut menjalankan sekedar mampunya). Murid-murid yang mencapai tingkatan khawas digembleng dan diharuskan tinggal di zawiyah-zawiyah (tempat penyepian). Biasanya murid seperti ini hanya sejumlah kecil dari calon elit, itupun biasanya dibagi atas tiga tingkatan ilmu mereka, yaitu tingkat mubtadi (permulaan), tingkat mutawasith (pertengahan), dan tingkat muntahi (tingkat atas atau puncak) (Simuh, 1997). 
TQN di Kabupaten Bandung tidak membedakan amaliah antar pengikut, pemuda atau orang dewasa amaliah ajarannya sama. Tetapi keistimawaan yang membedakan hanya pada jumlah bacaan dan penghayatan dalam menjalankannya (Wawancara dengan HM, Wakil Talqin TQN, 03/02/ 2020). Terdapat bentuk-bentuk amaliah yang diyakini sebagai wujud persembahan dalam rangka mendekatkan diri kepada Allah. amaliah tersebut dapat diklasifikasikan menjadi upacara keagamaan 'wajib', upacara keagamaan 'sunnah muakkad' dan upacara keagamaan 'sunnah'. Temasuk upacara keagamaan wajib, di antaranya bai'at atau talkin dan zikir. Upacara keagamanan sunnah muakkad meliputi; khataman, sholat sunnah dan manaqiban. Sementara itu, upacara keagamaan sunat meliputi zikir di luar yang disebutkan itu, terutama zikir khafi.

Baiat atau Talkin

Kegiatan pengajaran pertama yang harus dilalui seorang pengikut TQN, tanpa terkecuali, adalah talkin, yaitu upacara ritual pertama bagi seorang ikhwan baru untuk menerima peringatan dan penanaman ajaran tarekat dari guru mursyid. Dalam kesempatan itu, murid melakukan baiat, yaitu sumpah setia murid di hadapan guru untuk mengamalkan dan mengerjakan semua kebajikan yans diperintahkan kepadanya. Pada praktiknya, ikhwan yang ada di Kabupaten Bandung melakukan talkin dan baiat langsung dari guru mursyid tarekat, Abah Aos, di Pesantren Sirnarasa Kabupaten Ciamis Provinsi Jawa Barat. Atau menunggu Abah Aos mengikuti kegiatan manaqiban di daerah terdekat. Dan apabila masih tidak bisa secara langsung ke Mursyid maka diperkenakkan ke wakil talqin, yaitu orang yang ditunjuk oleh guru mursyid untuk memberikan dan menuntun ihkwan baru, untuk melayani calon ikhwan diseluruh dunia. Terdapat 182 wakil talqin (Saeful, n.d.).

Talkin diberikan kepada orang-orang yang ingin belajar zikir dengan benar, seperti yang diajarkan oleh guru-guru mursyid terdahulu, para ulama, atau wali yang mewarisi zikir. Dipercayai bahwa tidak sembarang orang mendapat wewenang khusus untuk kegiatan ini. Talqin merupakan salah satu cara bagi ikhwan pemula untuk melakukan zikir sesuai dengan ajaran TQN, yang selanjutnya bisa dipergunakan sebagai cara untuk mendekatkan diri kepada Allah, dan bisa mengerjakan perintah-Nya dengan hati yakin dan ikhlas.

Perlu diketahui bahwa proses pembaitan calon ikhwan TQN telah mengalami perubahan, pada zaman Abah Sepuh hanya orang yang sudah memasuki usia 40 tahun yang dapat baiat atau talkin, atau secara tidak langsung hanya orang yang berusia diatas 40 tahun yang dapat mengikuti ajaran TQN, kemudian terjadi perubahan di masa Mursyid Abah Anom, pada masa beliau memimpin batasan usia para pengitu TQN di mulai dari 17 tahun. Sedangkan pada era sekarang, era kemursyidan Aba Aos tidak ada batasan usia pembaiatan, siapa saja yang siap mengikuti ajaran TQN maka layak untuk dibaiat atau talkin. Bahkan proses pembaiatanpun pada era sekarang sangat dipermuda, jika melihat ajaran tarekat yang lain, proses pembaiatan menunggu waktu atau bulan khusus dengan prosesnya di zawiyah tersendiri. Sangat berbeda dengan tarekat ini, proses pembaiatan terbebas dari jarak dan waktu. Kapan saja dan dimana saja bisa memohon ke mursyid atau jika beliau berhalangan dapat ke wakil talkin, dan bahkan diera sekarang, proses pembaiatan dapat dilakukan secara online, dengan mengunakan aplikasi video call/telfon (Wawancara dengan DMY, pengikut TQN, 16/05/ 2020).

Secara umum talqin merupakan gabungan antara pengajaran tentang tata cara zikir dan nasihat tentang kebersihan hati. Proses talkin secara singkat seperti ini; mursyid memberi pepatah tentang keharusan ikhwan untuk lebih khusuk dalam menjalankan perintah agama sehingga dapat merasakan kehadiran Allah dalam semua kegaitan. Selanjutnya, guru mursyid memberi contoh tata cara zikir keras (jahr) dan zikir pelan (khafi). Zikir keras (jahr) diikuti para murid dengan mengucapkan "la illaha illallah" dengan suara dikeraskan serta dihentakan. Dengan pengalan lafadz berikut: "la" dicuapkan dengan ditarik dari kepala lebih tepatnya bagian ubun-ubun, kemudia lafadz "Ilaha" diucapkan berbarengan dengan menggerakkan kepada dimiringkan ke kanan, dan "illallah" diucapkan berbarengan dengan menggerakkan kepada dimiringkan ke kiri serta menghentakkannya ke jantung sebelah kiri. Kemudian zikir pelan (khafi), zikir ini lafadz-kan dalam hati sehingga tidak terdengar lantunannya. Proses penanaman zikir ini, diawali dengan kepala dituntukkan ke sebelah kiri serta mata 
terpejam, kemudian lidah menekan langit-langit mulut serta menutup mulut atau bibir rapat sambil berzikir dengan lafadz "Allah-Allah" secara terus menerus. Mursyid memberi komando bahwa talkin telah selesai dengan memerintahkan untuk mengamalkannya setiap waktu, terutama setelah selesai shalat wajib.

\section{Melaksanakan Zikir}

Ajaran pokok dalam TQN adalah zikir, terdapat dua macam zikir; zikir jahr dan Zikir khafi (Rusydati Khaerani \& Nurlaen, 2019). Tidak terdapat aturan secara khusus mengenai zikir khafi. Zikir ini dapat dilaksanakan kapan saja dan dimana saja. Soal waktu dan tempat zikir jahr tidak ada bedanya dengan zikir khafi, akan tetapi zikir jahr tidak bisa dilaksanakan pada saat bersama orang banyak. Selain itu, para ikhwan juga memiliki kewajiban untuk melaksanakan zikir ini setiap ba'da sholat wajib. berikut panduannya: (1) Bagi ikhwan TQN Pondok Pesantren Suryalaya diharuskan mengamalkan zikir kalimah Thoyyihah sekurang-kurangnya 165 kali. (2) Jumlah bilangan 165 dalam zikir adalah jumlah minimal, lebih banyak akan lebih baik dengan ketentuan diakhiri hitungan bilangan ganjil. (3) Bagi ikhwan yang mempunyai kesibukan seperti tengah melakukan safar (perjalanan), bisa membaca kalimah zikir dengan bilangan 3 kali. Namun di waktu-waktu senggang sebaiknya memperbanyak bacaan zikir, misalnya pada waktu setelah melaksanakan sholat malam. (4) Sebaiknya dilaksanakan berjama'ah dengan suara keras menghujam, sehingga "menghancurkan" kerasnya hati kita yang diliputi oleh sifat-sifat madzmumah (buruk) menjadi sifat mahmudah (baik). Atsar (bekas) dari zikir itu akan terlihat dengan perilaku pengamalnya yaitu membentuk pribadi pengamal zikir yang berakhlak mulia (Pondok Pesantren Suryalaya, 2014).

\section{Khataman}

Khataman merupakan kegiatan yang dilakukan oleh pemuda dan para ihkwan pengikut TQN di seluruh dunia. Khataman dapat dilakukan sendiri dan lebih dianjurkan untuk bersama-sama, di Kabupaten Bandung jika dilaksanakan bersama-sama biasanya dalam bentuk pertemuan kelompokkelompok ikhwan yang bertempat di masjid atau rumah salah seorang dari mereka. seringnya, dilakukan bergilir, minimal satu kali dalam seminggu, mereka melakukan zikir secara berjamaah dengan bimbingan mubalig atau wakil talkin setempat. Khotaman merupakan integrasi antara zikir, sholawat, do'a-do'a dan bacaan yang biasa diamalkan oleh Nabi dan para sahabat. Amaliah ini bisa dilaksanakan seminggu sekali, seminggu 2 kali atau tiap hari, dengan waktu setelah sholat sunat lidaf'il bala bada sholat isya (lebih diutamakan) atau bisa pada waktu lain (Pondok Pesantren Suryalaya, 2014).

\section{Manaqiban}

Masyarakat Indonesia yang beragama muslim, mungkin sudah tidak asing lagi dengan sebutan manaqiban. Manaqiban berasal dari kata manqobah yang berarti biografi atau kisah tentang keutamaan ilmu, kesolehan dan amal seseorang, kemudian disebabkan oleh akulturasi budaya indonesia khususnya di jawa menambah imbuan 'an' yang biasa diartikan bentuk kegiatan yang dilakukan. Jadi jika ditarik kesimpulan, manaqiban adalah kegiatan pembacaan/perenungan biografi kesolehan dan kealiman seorang tokoh agama. Manaqiban yang dilaksanakan oleh TQN adalah kegaitan dalam upaya khidmat dan ilmiah, yang sudah tersetruktur secara baik atau bahkan sudah melembaga dan telah membudaya di kalangan ihkwan tarekat untuk mengenang biografi kesalehan dan keilmuan Syeh Abdul Qodir Jaelani. Kegiatan manaqiban yang dilakukan oleh para pengikut TQN merujuk pada panduan yang telah ditetapkan oleh mursyid, yaitu: dimuali dari kegiatan pembukaan, pembacaan ayat suci al-qur'an, pembacaan sholawat, pembacaan tanbih, pembacaan tawasul, pembacaan manaqib syaikh abdul qodir jaelani, dan yang terakhir da'wah/tabliqul Islam.

Ikhwan memiliki kepercayaan terhadap kegiatan manaqiban bahwa "tidak ada pelaksanaan manaqiban sendiri, akan tetapi yang ada adalah dibaca sendiri". Artinya kepercayaan akan kehadiran Abdul Qodir Jaelani dan para guru tarekat ini telah mengakar dalam kehidupannya (Wawancara dengan DMY, pengikut TQN, 16/05/ 2020). 


\section{Sholat Sunnah}

Sholat sunnah sudah tidak asing lagi bagi semua masyarakat muslim di seluruh dunia, sholat yang dilakukan karena anjuran dari Nabi Muhammad SAW dan bukan perintah wajib, maksudnya barang siapa yang mengerjakannya akan mendapat pahala dan yang meninggalkannya tidak mendapatkan dosa. Bagi para pengikut ajaran TQN, terdapat keistimewaan tersendiri tentang pelaksanaan Sholat Sunnah, sholat sunnah sangat dianjurkan sampai menyerupai derajat wajib dan dikategorikan sebagai amalan harian. Selain itu, pelaksanaannya pun berdasarkan panduan dari Mursyid. Hal itu terlihat ketika kegiatan manaqiban atau khataman bersama para ikhwan TQN, semua ikhwan melaksanakan beberapa sholat sunnah dengan serentak, tanpa terkecuali (Wawancara dengan DMY, pengikut TQN, 16/05/ 2020). Berikut merupakan sholat sunnah yang diamalkan oleh ikhwan muda di Kabupaten Bandung: Shalat Isyraq, Shalat Dhuha, Shalat Sunnah Qobliyah, Shalat Sunnah Badiyah, Shalat Sunnah Awwaabiin, Shalat Sunnah TaubatShalat Sunnah Birrul Waalidain, Shalat Sunnah Hifzhil Iman, Shalat Sunnah Syukrun Ni'mat, Shalat Sunnah Daf'il Bala' dan Sholat Lailatul Qodar.

\section{Manfaat Ajaran}

Dewasa awal merupakan masa seseorang tumbuh menuju kematangan kedewasaan dan siap mendapatkan amanat dari lingkungan masyarakat (Putri, 2018). Karenanya masa ini menurut Erikson adalah masa untuk menemukan indentitas diri (siapa Anda?) yang dapat membangun definisi-diri untuk dapat berfungsi; dan Arnett menambahkan bahwa idealnya pada masa ini aspek-aspek esensial identik terbentuk; termasuk kemampuan untuk berfungsi secara independen dan dalam berhubungan dengan orang lain (Adcock \& Tucker, 2019, p. 631). Secara lebih rinci, teori yang digagas oleh Elizabeth B. Hurlock menunjukkan ciri-ciri masa dewasa awal sebagai berikut; periode dewasa awal sebagai masa pengaturan, masa bermasalah, masa usia reproduktif, masa ketegangan emosional, masa komitmen, masa keterasingan sosial, masa perubahan nilai, masa ketergantungan (ketergantungan pada hal yang dapat menjadikan sukses), masa penyesuaian diri dengan cara hidup baru, masa kreatif (Hurlock, 2002).

Periode ini dapat dikatakan sebagai periode paling berat dalam perkembangan manusia. Sebab, pada periode sebelumnya hampir semua anak memiliki orang tua, guru, teman atau siapa saja yang siap untuk menolong dalam proses penyesuaian diri (Anwar, Rizal, \& Rahman, 2018). Masa perkembangan ini, sebagai orang dewasa diharapkan dapat menghadapinya secara mandiri. Sering kali apabila mereka menghadapi masalah-masalah yang sukar diatasi, merasa malu meminta bantuan karena enggan dianggap "belum dewasa” (Hurlock, 2002).

Tarekat TQN sebagai jalan menuju kesucian jiwa yang dituntun oleh mursyid, memiliki pedoman tentang "kewajiban ikhwan kepada muryid" salah satunya adalah segala hal yang menyangkut dirinya (ikhwan) harus tetap mendapatkan arahan dan izin kepada mursyid (Alba, 2011). Tentunya, hal ini sangat relevan dalam menjawab masalah yang dihadapi pada periode perkembangan dewasa awal. Selain itu, berikut merupakan manfaat mengikuti tarekat pada masa perkembangan dewasa awal: bimbingan mursyid, menambah saudara, kebersamaan, menghindari penyimpangan, dan diri lebih terkontrol.

Yang pertama, bimbingan mursyid. Mursyid tidak saja mengajarkan tentang nikmatnya beribadah kepada Allah, tetapi beliau juga mengajarkan dan membimbing segala bentuk permasalahan. Hal itu tentulah sangat bermanfaat bagi perkembangan anak muda khususnya pada ciri masa bermasalah, ketegangan emosi dan ketergantungan, karena pada periode perkembangan ini ia sangat membutuhkan sosok seseorang yang dapat membimbing dan mengarahkannya tanpa ada rasa cangung. Proses bimbingan sekurangnya ada tiga macam: Pertama, mengikuti panduan amaliah dan adab-adab yang berlaku dalam tarekat. Kedua, mendapatkan arahan/bimbingan secara umum yang biasa dilaksanakan pada kegiatan manaqiban, khataman dan kegiatan-kegiatan umum lainnya. Ketiga, mendapat bimbingan khusus dengan cara berkonsultasi dengan mursyid.

Yang kedua, menambah saudara. Semua murid dalam TQN biasa disebut dengan ihkwan. Kata Ihkwan dari Bahasa Arab yang berarti saudara laki-laki, pengambilan sebutan ikhwan ini sendiri 
memiliki tujuan untuk mempererat persaudaraan antar murid. Manfaat ini tentu dapat menjadi solusi setidaknya pada ciri perkembangan masa keterasingan sosial dan dengan cara hidup baru.

Yang ketiga, kebersamaan dan solidaritas. Doktrin sufi yang mengajarkan kebersamaan antar pengamal tarikat menjadi kelebihan tersendiri dalam tarikat. Dalam sebuah kelompok yang setiap hari terus dipupuk adanya rasa kebersamaan dan solidaritas individu, memungkinkan untuk terus saling berhubungan dan akan tercipta suasana keakraban yang semakin menipiskan bentuk perbedaan yang ada. Jadilah di antara mereka tak lagi ada rasa segan untuk sekedar saling mengingatkan, membantu bila ada yang membutuhkan, dan kebutuhan lain yang lazim ada dalam sosialan. Keadaan ini membuat para ikhwan semakin nyaman dan mudah untuk mengkontekstualisasikan tasawuf dalam kehidupan sehari-hari. Selain itu, solidaritas pun tercipta yang dapat membantu pola perkembangan anak muda, setidakanya salah satunya adalah terbangun relasi antar ikhwan, saling tukar pengalaman positif yang dapat memupuk semangat menggapai prestasi, memperluas wawasan dan memperluas pergaulan. Manfaat ini tentu dapat menjadi solusi setidaknya pada ciri perkembangan masa usia reproduktif, masa komitmen, masa keterasingan sosial, masa kreatif dan masa penyesuaian diri dengan cara hidup baru.

Yang keempat, mengindari penyimpangan dalam ajaran agama. Manfaat ini tentu dapat menjadi pemutus penyebaran gerakan radikalisme dan terorisme bagi anak muda, kerena ajaran tarekat ini sudah memiliki kejelasan mengenai sanad yang sampai kepada Nabi Muhammad Saw, inilah kelebihan ajaran tarekat yang sangat menjaga sanad ajarannya. Manfaat ini tentu dapat menjadi solusi setidaknya pada ciri perkembangan masa komitmen, dan masa perubahan nilai.

Yang kelima, diri lebih terkontrol. Hal ini terkait dengan keketatan dan kedisiplinan dalam sistem tarikat. Dengan adanya sebuah manaemen dalam sebuah kelompok, akan semakin memperkecil kesempatan diri untuk lari dari tanggungjawab dan bermalas-malasan. Pengontrolan diri oleh lingkungan tarekat sangatlah bernanfaat untuk menumbuhkan rasa malu dalam diri. Rasa malu untuk tidak mengikuti kegiatannya, malu ketika melakukan maksiat atau membuka aurat.

\section{Kesimpulan}

Penelitian kualititatif dengan menggunakan metode studi pustaka mengkaji mengenai fenomena pemuda penganut TQN di Kabupaten Bandung menunjukkan bahwa perkumpulan pemuda tersebut berlatar belakang pendidikan yang bervariasi, dimulai dari SMP (Sederajat) sampai Sarjana dengan didominasi berpendidikan SMA (Sederajat) serta pekerjaannya pun bermacam-macam; buruh, guru, pelajar dan lain sebagainya. Meskipun demikian, ajaran tarekat ini tidak membedakan dari segi materiil, dan pekerjaan. Pemilihan aliran tarekat dilatarbelakangi oleh Landasan filosofis pragmatis instrumental (al-dzarai'iy) dengan proses pengambilan keputusan yang berbeda-beda tetapi memiliki tujuan yang sama yakni pendalaman ilmu agama. Serta ajaran tarekat yang biasanya dianggap hanya untuk orang tua, ternyata dipelajari dan dijalankan anak muda akan sangat membantu dalam menghadapi masa perkembangannya.

\section{Referensi}

Abdurrahman, M. S. (2020). Generasi Muda, Agama Islam, dan Media Baru : Perilaku Keagamaan Gerakan Shift Pemuda Hijrah Bandung. Anida (Aktualisasi Nuansa Ilmu Dakwah), 20(1), 46-63.

Adcock, S. S., \& Tucker, C. (2019). Konseling Anak-anak dan Remaja (H. P. Soetjipto \& S. M. Soetipto, Trans.). Yogjakarta: Pustak Pelajar.

Alba, C. (2011). Cahaya Tasawuf (2nd ed.). Bandung: Wahana Karya Grafika.

Anwar, R. K., Rizal, E., \& Rahman, M. T. (2018). Consideration of Parents' Beliefs about Guiding Children's Usage of the Internet. 4th International Conference on Contemporary Social and Political Affairs (ICoCSPA 2018), August 13-15, 2018, Surabaya, Indonesia.

Atjeh, A. B. (1996). Pengantar Ilmu Tarekat. Solo: Ramadhani.

Bruinessen, M. van. (1992). Tarekat Naqsyabandiyah di Indonesia. Bandung: Mizan.

Hariko, R. (2017). Landasan Filosofis Keterampilan Komunikasi Konseling. Jurnal Kajian Bimbingan Dan Konseling, 2(2), 41-49. https://doi.org/10.17977/um001v2i22017p041

Hurlock, E. B. (2002). Psikologi Perkembangan (Suatu Pendekatan Sepanjang Rentang Kehidupan) (R. M. Sijabat, Ed.; 
Istiwidayanti \& Soedjarwo, Trans.). Jakarta: Erlangga.

Ismail, A. U. (2018). Fenomena Tarekat di Zaman Now (Telaah atas Ajaran dan Amalan). Dakwah: Jurnal Kajian Dakwah Dan Kemasyarakatan, 22(2), 199-216. https://doi.org/http://doi.org/10.15408/dakwahv22i1.12068 Pendahuluan

Jalaluddin. (2015). Psikologi Agama (Memahami Perilaku dengan Mengiplikasikan Prinsip-prinsip Psikologi). Depok: Rajawali Pers.

Kahmad, D. (2002). Tarekat dalam Islam; Spiritual Masyarakat Modern. Bandung: Pustaka Setia.

Kurniawan, F. (2019). Pengembangan Teori Pendidikan Islam Perspektif Muhammad Jawwad Ridla (Religius Konservatif, Religius Rasional, Pragmatis Instrumental). At-Ta'lim : Media Informasi Pendidikan Islam, 18(1), 223. https://doi.org/10.29300/attalim.v18i1.1823

Masduki, Hartono, T., \& Rosidi, I. (2017). Harmoni Lingkungan dan Pengikut Tarekat Qadiriyah Wa Naqsabandiyah Lalang Tanjung, Riau. Al-Tahrir, 17(2).

Mashar, A. (2016). Genealogi dan Penyebaran Thariqah Qadiriyah wa Naqshabandiyah di Jawa. Al-A'raf: Jurnal Pemikiran Islam Dan Filsafat, 13(2), 233-262.

Nasution, H. (2018). Islam ditinjau dari berbagai aspeknya. Jakarta: UI-Press.

Nawawi, I. (1314). Maraqi Al-Ubudiyah Syarh Bidayah Al-Hidayah. Mesir: Dar Al-Kutub Al-Islamiyah.

Pondok Pesantren Suryalaya. (2014). Kitab Uquudul Jumaan (3rd ed.; S. M. A. G. Saefulloh, Ed.). Bandung: CV Wahana Karya Grafika.

Putri, A. F. (2018). Pentingnya Orang Dewasa Awal Menyelesaikan Tugas Perkembangannya. SCHOULID: Indonesian Journal of School Counseling, 3(2), 35. https://doi.org/10.23916/08430011

Riyadi, A. (2014). Tarekat Sebagai Organisasi Tasawuf (Melacak Peran Tarekat dalam Perkembangan Dakwah Islamiyah). Jurnal At-Taqaddum, 6(2), 359-385.

Rusydati Khaerani, I. F. S., \& Nurlaen, Y. (2019). Makna Simbolik Zikir Pada Jemaah Tarekat Qadiriyah Naqsabandiyah (Studi Kasus Pada Jemaah Tarekat Naqsabandiyah di Pondok Pesantren Sirnarasa Ciamis). Jurnal Studi Agama Dan Masyarakat, 15(2), 87-97. https://doi.org/10.23971/jsam.v15i2.1331

Saeful, M. A. G. (n.d.). Amaliyah Mursyid.

Simuh. (1997). Tasawuf dan Perkembangannya dalam Islam (2nd ed.). Jakarta: Rajawali Pers.

Syam, N. (2013). Tarekat Petani (Fenomena Tarekat Syattariyah Lokal). Yogyakarta: LKiS.

Tim Karya Ilmiah Purna Siswa. (2014). Jejak Sufi: Membangun Moral Berbasis Spiritual (3rd ed.). Kediri: Lirboyo Press. Undang-Undang Republik Indonesia Nomor 40 Tahun 2009. (n.d.).

Widyaningsih, R., Sumiyem, \& Kuntarto. (2017). Kerentanan radikalisme agama di kalangan anak muda. Prosiding Seminar Nasional Dan Call for Papers "Pengembangan Sumber Daya Perdesaan Dan Kearifan Lokal Berkelanjutan VII", 1553-1562. Purwokerto.

Wishnugroho Akbar. (2018). BIN Ungkap 39 Persen Mahasiswa Terpapar Radikalisme. Retrieved from CNN Indonesia website: https:/www.cnnindonesia.com/nasional/20180429023027-20-294442/bin-ungkap-39persen-mahasiswa-terpapar-radikalisme

(C) 2020 by the authors. Submitted for possible open access publication under the terms and conditions of the Creative Commons Attribution (CC BY SA) license (https://creativecommons.org/licenses/by-sa/3.0/). 
Halaman ini sengaja dikosongkan 